\title{
The political economy of universal pensions in Bolivia
}

\author{
Katharina MÜLLER \\ Mannheim University of Applied Sciences
}

\begin{abstract}
While non-contributory pensions are spreading around the globe, Bolivia is still the only Latin American country with a universal old-age pension scheme. Originally designed twenty years ago and contested more than once, the benefit survived a political regime change from neo-liberalism to new developmentalism and features an interesting political economy. With the commodities boom coming to an end, progressive neo-extractivism and thus, Bolivia's universal pension, face new challenges.
\end{abstract}

Keywords: cash transfer, universal pension, political economy, developmentalism, extractivism

\section{Introduction ${ }^{1}$}

Almost 70 years have elapsed since the UN General Assembly's avowal that "everyone, as a member of society, has the right to social security" (1948: Art. 22). Despite the long history of the Universal Declaration of Human Rights, many elderly persons, especially in the global South, find themselves unable to fulfil their basic needs (Shahid 2014). Many older Latin Americans have no social security to rely on, even though regional pioneers adopted Bismarck-style pension schemes as early as the 1920s. The 1980s and 1990s saw a radical shift towards pension privatisation (Müller 2003; Orenstein 2008, 2011). The paradigm change failed to improve coverage, however, particularly among women and in the rural and informal sectors (Mesa-Lago 2008, 2014). Only a minority of Latin Americans are covered by contributory pension schemes, be they publicly or privately managed (OECD/IDB/World Bank 2014: 14-15).

It is in this context that non-contributory transfers finally provide benefits to vulnerable elderly in Latin America (Hillenkamp 2013: 51). Under such schemes, payroll contributions are not a prerequisite for entitlement (Barrientos/Lloyd-Sherlock 2002; HAI 2004; Ginneken 2007). Non-contributory benefits have become increasingly common around the globe, not least since the Social Protection Floor Initiative (ILO 2011). While a number of Latin American countries introduced non-contributory pensions in recent years, these schemes are gener-

\footnotetext{
${ }^{1}$ This article analyses the most recent developments building on previous articles (Müller 2009, 2012). The author would like to thank Monica Budowski, Daniel Künzler, and anonymous reviewers for helpful comments and suggestions.
} 
ally means-tested. ${ }^{2}$ Only Bolivia's non-contributory pension is payable to all elderly citizens. Though strikingly modest at US\$460 per annum (p.a.), it challenges the targeting paradigm prevailing in Latin America and is a pioneer in the region (Cotlear 2011: 14). Remarkably, Bolivia is also South America's poorest country.

Over the past two decades, Bolivia's non-contributory, universal pension scheme has received only limited international attention. This article focuses on the peculiar political economy of Bolivia's universal pension. Conceived by neoliberal structural reformers under the name of Bonosol, the scheme was first challenged, then appropriated by the current left-wing government and renamed Renta Dignidad. ${ }^{3}$ This also changed the benefit's main financing source from dividends to hydrocarbon taxes. With the commodity boom going into reverse, the country's revenue envelope is tightening, thus challenging the very basis of Bolivia's "neoextractivist developmentalism" (Veltmeyer 2014: 111).

The next section provides details on the eventful fate of Bolivia's universal pensions, from the unusual genesis of the Bonosol scheme and its replacement by Renta Dignidad to the end of the hydrocarbon bonanza. The following section looks at the rationale of Bolivia's universal pension amid changing development paradigms and social policy regimes. Subsequently, a critical appraisal of the non-contributory benefit is ventured. The concluding section sums up the main lessons learnt from the Bolivian case.

\section{A timeline of Bolivia's universal pensions}

\section{Linking pension and enterprise privatisation: the genesis of the Bonosol}

Bolivia's universal, non-contributory pension was devised in the mid 1990s in the context of Washington Consensus-type structural reforms. These were launched during Gonzalo Sánchez de Lozada's first presidency (1993-1997). The political party represented by Sánchez de Lozada - the Nationalist Revolutionary Movement (MNR) - had led Bolivia's 1952 revolution but now dismantled the state-led development model with an "almost messianic modernising zeal" (Bauer/Bowen 1997: 3). Neoliberal reforms were endorsed by the international financial institutions (IFIs) in "a decade-long policy dialogue to reduce the public sector's presence" in Bolivia (World Bank 2000: 4).

The shift from a public pay-as-you-go (PAYG) to a private, individually fully funded (IFF) pension scheme and the privatisation of state-owned enterprises were two key projects on Sánchez de Lozada's agenda. Both reforms were highly controversial and made more politically palatable by a major conceptual and semantic effort. Eventually, this included linking both projects through a universal pension scheme (Ministerio de Capitalización 1997; Peirce 1997).

For a start, the transfer of state-owned enterprises to private control, legislated in March 1994, was called "capitalisation" to avoid the politically sensitive term "privatisation". The

\footnotetext{
${ }^{2}$ In this article, the term "Latin America" refers to the parts of the American continent where Spanish or Portuguese is the main national language. For an overview on non-contributory pensions in the region see Dethier/Pestieau/Ali (2010), Bosch/Melguizo/Pagés (2013) and Rofman/Apella/Vezza (2013).

${ }^{3}$ On Bonosol and Renta Dignidad see Martínez (2004), Aponte et al. (2006), Willmore (2006), Yanez-Pagans (2008), Ossio (2009), Ticona Gonzales (2011) and Escobar Loza/Martínez Wilde/Mendizábal Córdova (2013).
} 
largest state-owned enterprises were transformed into joint stock companies to allow for an injection of fresh capital and avoid their outright sale. Thereafter a strategic investor, selected in an international bidding process, doubled the existing capital. ${ }^{4}$ The remaining state-owned shares - roughly half the shares of the capitalised companies - were administered by newly established mandatory private pension funds (AFPs). The dividends generated by these shares were distributed among the population. The declared aim of this peculiar package was to "ensure that Bolivians benefit from their assets" (Sánchez de Lozada 1993: 3). ${ }^{5}$

Sánchez de Lozada had announced the need for structural reforms in his election manifesto, "Plan de Todos" (Plan for All). However, most versions of the Plan did not mention pension privatisation. The Bonosol was not mentioned either. According to the Plan, state-owned shares were to be administered by a Foundation for Development in Solidarity (Fundesol) to finance community projects. Subsequently, shares were to be distributed free of charge among all adult Bolivians (Sánchez de Lozada/Cárdenas 1993). In a popular edition, this form of mass privatisation was characterised as "a radical redistribution of wealth, only comparable to the one that was brought about by land reform” (MNR/MRTK 1993: 20).

In early 1994, following discussions with international experts, reformers decided to abandon the Fundesol idea, while the link with pension privatisation gained importance. Now, a rather complex model was designed: private pension funds would administer state-owned shares and credit dividends to deferred share distribution accounts, to be opened for all adults. All individual shares plus capitalised dividends were to be converted into retirement benefits when beneficiaries would reach age 60 (Mercado Lora 1998; World Bank 1995). However, pension fund administrators - the institutional channel for the transfer of resources from the state to its citizens - had yet to be created. The 1994 Capitalization Law thus prescribed subsequent legislation on pension funds (Ley No. 1544), establishing a firm link between Bolivian-style privatisation and structural pension reform.

A few months later, reformers started a public relations campaign to improve the acceptance of pension privatisation. ${ }^{6}$ The move was supported by the business community and the financial sector, but pensioners' associations and the Bolivian trade union confederation, $\mathrm{COB}$, remained staunchly opposed to neoliberal economic policy, including pension privatisation. Opponents voiced their protest in public debates, protest marches, and a 24-hour general strike. By the mid-1990s, these groups had lost much clout but were still strong enough to delay the submission of pension reform laws to Congress (Gamarra 1997; Morales 1995).

Sánchez de Lozada was keen to complete the capitalisation programme, however, of which private pension funds now formed an integral part. Moreover, one tranche of a World Bank Adjustment Credit had been made conditional on the privatisation of pensions. By 1996, it had become clear that this paradigm change would have to be legislated and implemented in the run-up to general elections, held in 1997. The government then decided to redesign the

\footnotetext{
${ }^{4}$ By June 1997, private investors had taken a majority stake in the power, oil and gas sectors, the railroads, the national airline and telecommunications (Baldivia Urdininea 1998). The state ended up holding an average of $45.8 \%$ of the capital, although the original plan had read: "we Bolivians will hold the majority - not less than 51\%" (Sánchez de Lozada 1993: 3). Employees bought the remaining $4.2 \%$ of shares (SPVS 2000).

${ }^{5}$ All Spanish quotations were translated by the author.

${ }^{6}$ For detailed accounts of the political economy of pension privatisation in Bolivia, see Gray-Molina, Pérez de Rada/Yañez (1999), Müller (2001, 2003), Pérez (2000) and Weyland (2005).
} 
link between capitalisation and pension reform, creating the Bonosol. Up to now, pension privatisation had mainly been framed in macroeconomic terms (see, e.g., Mercado Lora 1998: 180). Contrary to this, the innovative Bonosol scheme promised tangible, immediate benefits to elderly citizens once private pension funds were established. The new approach was chosen "first, due to its simplicity; second, because a largely ignored part of the population would benefit; and third, due to the positive public image that this measure would create" (Mercado Lora 1998: 156).

In mid 1996, the pension reform law, closely modelled on the Chilean prototype, was sent to Congress. After a failed effort at broader consensus-building, the government decided to use its ample parliamentary majority to pass the law in November 1996. Hence, the Bonosol scheme was primarily designed to complicate opposition to pension privatisation. For example, the pensioners' federation found itself in an uncomfortable position:

"[W]e argue ... that the pension reform law is unconstitutional and should be revoked - yet this law also establishes the Bonosol. Hence we get tied up in contradictions because we defend the Bonosol" (CNJRB 1998: 50).

The World Bank and the Inter-American Development Bank, although strong supporters of Bolivia's structural reforms, opposed the Bonosol (Ballivián 1997; Graham 1998). Instead of handing out capitalisation proceeds to elderly Bolivians, the IFIs strongly suggested using them to cover the high fiscal cost of pension privatisation. ${ }^{7}$

\section{From Bonosol to Bolivida, and back}

The distinctive feature of Bolivia's first universal pension scheme, the Bonosol, was its tie with pension reform and enterprise capitalisation. In May 1997, both private pension funds, AFP Futuro de Bolivia and BBVA Previsión AFP, started administering two funds each - the individual and the collective capitalisation funds, known as FCI and FCC, respectively. The FCI comprised the sum of all individual accounts, while the FCC was made up of the formerly state-owned part of the capitalised enterprises. ${ }^{8}$ The latter was meant to make the small Bolivian pensions market more attractive for international investors. The dividends generated by the FCC were to be distributed through the Bonosol, an annual payment of 1,300 Bolivianos (Bs.) - then US $\$ 248$ - to all Bolivians above age 65 , in order to create domestic stakeholders in both capitalisation and pension privatisation.

There was one peculiarity, though: payments were restricted to Bolivians who had reached the age of majority by 31 December 1995 . The assumption underlying this cohort restriction was that the above-mentioned group of citizens had contributed - as workers or taxpayers to Bolivia's state-owned enterprises, which had ceased to exist in 1995. Reformers argued that "through their efforts, the aged enabled the creation and consolidation of the capitalised state firms, and that this was the reason why this benefit belonged to them" (Mercado Lora 1998:

\footnotetext{
${ }^{7}$ After the World Bank's discovery of "zero pillars" (Holzmann/Hinz 2005: 42), it endorsed the Bonosol in principle, but pointed out possible improvement (Gill/Packard/Yermo 2005; Rofman 2006).

${ }^{8}$ The FCC was valued at US $\$ 2.6$ billion at the end of 1997 , while the FCI had accumulated US $\$ 2.2$ billion as of November 30, 2006 (SPVS 2000, 2006).
} 
160). With dwindling numbers of beneficiaries, FCC shares were to be liquidated. The idea was to exhaust the FCC upon the death of the last beneficiary.

In May 1997, shortly before the general election, Bonosol payments commenced. They did not prevent Sánchez de Lozada's electoral defeat, even though the new benefit met with an overwhelming response from the aged all over the country. Payable by the AFPs upon presentation of one's identity card, the Bonosol conveyed substantive citizenship rights by convincing many elderly to apply for papers for the first time in their lives (Whitehead 1997; Skinner 2006). Given that 364,261 instead of the expected 295,000 beneficiaries turned up, the available liquidity proved insufficient to cover payments, with the AFPs resorting to loans to meet their obligations.

The incoming administration (1997-2001) of Hugo Banzer stopped the Bonosol in January 1998, censuring it as unsustainable. Six months later, it was replaced with a less generous scheme called "Bolivida", which started to pay out benefits only in December 2000. Under the Bolivida scheme an annual pension of only US $\$ 60$ was paid, in national currency, to those aged 65 and above, and limited to those who were over 50 years old at the end of 1995. In addition, drawing on the original concept of his political opponent, Banzer had promised to distribute a large part of the FCC in the form of "popular shares" to Bolivians between the ages of 21 and 50. This programme proved impossible to conceptualise, as both the numerator (the market value of the unlisted shares of capitalised firms) and the denominator (the size and age distribution of the Bolivian population) were unknown quantities.

When Sánchez de Lozada returned to power in 2002, his first major legislative initiative was to reinstate the Bonosol (Ley No. 2427) - a campaign promise. Annual payments resumed in 2003 at 1,800 Bs. (then US\$240). It soon turned out, however, that the liquidity needed for Bonosol payments exceeded FCC dividends by far - again. Thus, the government required the AFPs to start liquidating FCC shares by purchasing them for their FCI portfolio (WithersGreen 2003). This move met with fierce resistance from both AFPs and their members less than enthusiastic about a forced investment of their retirement savings in illiquid shares of former state-owned enterprises. After the sale of $2 / 24$ parts of the FCC, the measure was stopped and later revoked.

\section{Re-nationalising hydrocarbons: the Bonosol's demise}

Amidst general dissatisfaction with market-oriented reforms, President Sánchez de Lozada was ousted from power in October 2003, following weeks of violent protests over gas exports. In 2004, a referendum held in response to the unrest spelled further trouble to the Bonosol scheme, as voters overwhelmingly decided that the state was to regain control over the gas sector. Given that the shares of the oil and gas companies (Transredes, Petrolera Chaco and Petrolera Andina) constituted the most profitable part of the FCC, there were immediate fears that this move towards developmentalism would severely hamper the fund's capacity to generate dividends - and, thus, to finance the Bonosol.

In May 2005, the Hydrocarbons Law proclaimed national ownership of all reserves up until the well-head, and a Direct Hydrocarbons Tax (IDH) was introduced (Hodges 2007). In December 2005, Socialist leader Evo Morales won the presidential elections, taking office in January 2006. The election manifesto of his "Movement Towards Socialism" (MAS) called for 
direct state control over all capitalised enterprises, while also guaranteeing Bonosol payments from FCC dividends and from the general government budget (Rofman 2006: 398).

On May 1, 2006, President Morales decreed national ownership of the oil and gas industry, obliging capitalised companies to sign new contracts with the Bolivian state, while failure to do so would mean expropriation. In December 2006, Bolivia completed its gas nationalisation programme, giving the state control over the operations of foreign energy firms in the country. ${ }^{9}$ The main effects of the new legislation have been: (i) a transition from risk-sharing contracts with foreign companies to an arrangement whereby all production was surrendered to the state energy company, YPFB; (ii) an increase in natural gas royalties, from 18 to $50 \%$ of turnover; and (iii) a requirement that YPFB regain control over the hydrocarbons companies capitalised in the 1990s (IMF 2007: 7).

The fundamental changes brought about in the gas sector since 2005 - from neoliberalism to progressive neo-extractivism (Gudynas 2010) - impacted on the institutional framework created by the architects of capitalisation. Nevertheless, the initial mantra was that the Bonosol would continue to be paid. In its Article 6, the Hydrocarbons Law of 2005 stated that financing for the Bonosol would be guaranteed in spite of the FCC's restructuring (Ley No. 3058). The Nationalization Decree of 2006 stipulated a free transfer of shares of some companies from the FCC to YPFB, while guaranteeing the reimbursement of the dividends formerly paid to the Collective Capitalization Fund (Decreto Supremo No. 28701, Art. 6).

Those reassurances notwithstanding, doubts were rising as to how the Bonosol could be funded in the context of re-nationalisation. In May 2006, the shares of Transredes, Petrolera Chaco and Petrolera Andina were transferred from the FCC to YPFB, and in April 2007, all Entel shares were returned to the state. Those four companies had provided most of the dividends for the universal pension scheme. In theory, their dividends should have been made available for Bonosol payments. Yet, unpaid dividends to the FCC were almost daily news in early 2007.

The Minister of Finance promised to cover the shortfall with YPFB's surpluses, but the Minister of Hydrocarbons opposed the idea. He called the Bonosol "unsustainable" and stressed the necessity to strengthen YPFB as a development actor (La Razón 2007c). This conflict exemplifies that key architects of re-nationalisation prioritised alternative uses of profits. Similarly, in July 2007, Transredes' shareholders decided not to pay dividends but to invest surpluses in infrastructure, while in July 2007 President Morales announced the imminent nationalisation of railroads, another part of the FCC. By mid 2007 the FCC had only received dividends worth US\$36 million, instead of the US $\$ 100$ million annually needed to keep up Bonosol payments.

\section{From Bonosol to Renta Dignidad}

A decade after it was first paid, the low level of dividends paid into the FCC placed the Bonosol in immediate financial peril. In September 2007, the Morales administration identified an additional source of financing for the Bonosol: the Direct Hydrocarbons Tax, introduced in

\footnotetext{
${ }^{9}$ Only gas at the well-head was nationalised. Because of a lack of technical and financial capability, the state energy company YPFB would have found it difficult to take over the infrastructure (ICG 2007).
} 
2005 and channelled to different public entities according to a fixed allocation formula. The government's plan was to reduce the IDH share to be received by the Treasury, regions, municipalities and universities in order to meet Bonosol payments. The cutback plan predictably proved extremely unpopular and met with fierce resistance from regions, municipalities and universities, although the government had called for solidarity with Bolivia's elderly (La Razón 2007b).

In October 2007, President Morales announced the abolition of the Bonosol. The benefit would be paid only until the end of the year and then be replaced with a new pension, "Renta Dignidad". The non-contributory pension was continued with a new design: (i) eligibility was expanded to citizens above the age of 60; (ii) the restriction to elderly born before 1975 was dropped; (iii) the annual benefit amount was increased by $25 \%$, from 1,800 Bs. (currently US\$255) to 2,400 Bs. (US\$340), or 200 Bs. (US\$28) per month; (iv) a differentiation in benefit levels was introduced, granting recipients of a contributory old-age pension only 1,800 Bs., or 150 Bs. (US\$21) per month (Ley No. 3791).

The president thus symbolically discontinued the Bonosol, while branding his own universal pension. Morales claimed the political ownership of the non-contributory benefit, which he defined as an obligation to the elderly (La Razón 2007a). Without the former cohort restriction, Renta Dignidad was turned into a truly universal old-age pension (Escobar Loza/Martínez Wilde/Mendizábal Córdova 2013: 103). The much-called-for differentiation in benefit levels was designed in a blame-avoiding way: recipients of a contributory pension were not made worse off, but continued to receive 1,800 Bs. The creation of a larger constituency receiving a higher benefit enabled additional credit claiming for Renta Dignidad, while also providing crucial support in the on-going search for funding. Morales thus opted for the exact opposite of Banzer's 1998 approach to the Bonosol, who - when replacing it with the Bolivida - paid a substantially lower benefit to a smaller constituency (see Table 1).

Beyond symbolism and political credit claiming, the discontinuation of the Bonosol had also become a necessity in the context of re-nationalisation. Under Law No. 2427, the FCC would have been exhausted upon the death of the last beneficiary, i.e. all shares would be liquidated to cover Bonosol payments. "Thus, over time, we Bolivians would have lost our ownership of strategic companies entirely, e.g. in the hydrocarbons sector" (Embajada de Bolivia en la República Argentina 2007: 2). By contrast, Renta Dignidad would not conflict with the new political project, on the contrary:

"It is the concrete result of the nationalisation of our natural resources. Resources that now go directly to the hands of those people that need them most. It is a sustainable measure that neither implies privatising our state-owned enterprises nor losing our wealth and patrimony forever." (Viceministerio de la Descentralización 2008: 2). 


\begin{tabular}{lccc}
\hline Year & $\begin{array}{c}\text { Type of } \\
\text { pension }\end{array}$ & $\begin{array}{c}\text { Annual amount } \\
\text { (in Bs.) }\end{array}$ & $\begin{array}{c}\text { Number of } \\
\text { recipients }\end{array}$ \\
\hline 1997 & Bonosol & 1,300 & 364,261 \\
1998 & Bolivida & 395 & 318,529 \\
1999 & Bolivida & 395 & 340,403 \\
2000 & Bolivida & 420 & 334,371 \\
2001 & Bolivida & 420 & 351,166 \\
2003 & Bonosol & 1,800 & 448,864 \\
2004 & Bonosol & 1,800 & 458,914 \\
2005 & Bonosol & 1,800 & 482,002 \\
2006 & Bonosol & 1,800 & 487,832 \\
2007 & Bonosol & 1,800 & 493,437 \\
2008 & Renta Dignidad & $2,400 / 1,800$ & 752,519 \\
2009 & Renta Dignidad & $2,400 / 1,800$ & 779,810 \\
2010 & Renta Dignidad & $2,400 / 1,800$ & 802,073 \\
2011 & Renta Dignidad & $2,400 / 1,800$ & 823,499 \\
2012 & Renta Dignidad & $2,400 / 1,800$ & 855,529 \\
2013 & Renta Dignidad & $3,000 / 2,400$ & 887,156 \\
2014 & Renta Dignidad & $3,250 / 2,600$ & 917,018 \\
2015 & Renta Dignidad & $3,250 / 2,600$ & 923,918 \\
\hline
\end{tabular}

Table 1: Bolivia's universal pensions, 1997-2015. Note: The short-lived Bolivida was paid retroactively in two installments: from December 2000 to June 2001, the annual pensions of 1998 and 1999 were disbursed, and from December 2001 to June 2002, the annual pensions of 2000 and 2001. Sources: APS (2015: 2); Escobar Loza/Martínez Wilde/Mendizábal Córdova (2013: 104).

After the Renta Dignidad bill had been submitted to Congress, it was approved twelve days later without much consensus-building. The opposition then threatened to block the law in the Senate. The universal pension was to be financed partly by a substantial cut in regional IDH funds, while municipalities were to be compensated and universities exempted. The envisaged change in resource allocation stirred strong resistance, strikes and marches in the regions, especially in those governed by the opposition. Contrary to this, the scheduled benefit was popular with MAS supporters and the elderly. The pensioners' federation, supported by peasants' organisations, trade unions and other social groups, marched in favour of Renta Dignidad.

In November 2007, the Senate passed a modified bill, specifying alternative sources of financing for the universal benefit. Four days later, however, MAS legislators and a handful of other members of Congress passed the original law in the absence of opposition representatives (Hodges 2007). Eventually, President Morales promulgated Law No. 3791 on November 28, 2007. Benefit payments started on February 1, 2008.

With 752,519 beneficiaries, Renta Dignidad had twice as many recipients in 2008, its first year of operation, than the Bonosol in 1997. This was mainly due to Renta Dignidad's lower 
eligibility age, but also to population ageing and to improvements in coverage, already reflected in a 35\% hike in Bonosolistas between 1997 and 2007, from 364,261 to 493,437 (see Table 1). In 2015, Renta Dignidad was paid to 931,508 recipients, or $8.5 \%$ of Bolivia's population. There were 2.5 times more beneficiaries than at the Bonosol's start in 1997, when only $4.6 \%$ of Bolivia's population received a universal pension. At present, most beneficiaries receive the equivalent of US $\$ 460$ p.a., instead of US\$248 at the start of the universal pension scheme, an $85 \%$ increase ( $150 \%$ in domestic currency).

\section{From the consolidation of Renta Dignidad to collapsing commodity prices}

During the first decade of its existence, Bolivia's universal pensions was neither anchored in pension law nor in a human rights agenda. This omission was tackled soon after Renta Dignidad's introduction. In a referendum held in January 2009, a new constitution was approved by $61 \%$ of voters. Its preamble marked a departure from the neoliberal state of the past towards a "Unified Social State of Pluri-National Communitarian law" (Nueva Constitución Política del Estado 2009: 2). In this context, constitutional protection of Bolivia's universal pension was reached by interplay of Art. 45. IV ("The State guarantees the right to retirement, which is universal, supportive and equitable.") and Art. 67. II ("The State shall provide an old age pension within the framework of full social security, in accordance with the law."). Finally, preceded by a four-year negotiation process, the 2010 pension reform integrated the universal benefit into the new pensions architecture, now consisting of a contributory tier, a semicontributory tier, and a non-contributory tier (Ley No. 65), the latter represented by Renta Dignidad. ${ }^{10}$

As shown in Table 1, Renta Dignidad was increased twice. In May 2013, the regular benefit amount was raised to 3,000 Bs. p.a. (currently US\$425), or 250 Bs. (US\$35) per month, while recipients of a contributory old-age pension received 2,400 Bs. (US\$340) p.a., or 200 Bs. (US\$28) per month. From November 2014, a christmas bonus was added, raising the regular benefit amount to 3,250 Bs. (US\$460) annually, while recipients of a contributory pension now receive 2,600 Bs. (US\$368) p.a. In the ceremony kick-starting the christmas bonus, Evo Morales stressed that the pension was no longer paid by selling off state-owned companies, but by Bolivia's natural resources (La Razón 2014).

In the context of the universal pension's political consolidation, it is interesting to note the introduction of two other cash transfers, directed to school age kids (Bono Juancito Pinto, in 2006) and to pregnant women and newborns (Bono Juana Azurduy, in 2009). Both are designed as conditional cash transfers (CCTs), however, thus contrasting with the unconditional Renta Dignidad and not quite matching its distributional success (Vargas/Garriga 2015: 13). As indicated by the IMF (2015: 18), these three programs benefitted around 30\% of Bolivia's total population at $1.5 \%$ of the country's gross domestic product (GDP) in 2014.

Bolivia's success in reducing poverty and inequality over the last decade has been recognized by many observers (see, e.g., ECLAC 2015; Vargas/Garriga 2015). Poverty was cut from $63 \%$ in 2002 to $39 \%$ in 2013, whereas the Gini coefficient was lowered from 0.60 to 0.49 over the same period (World Bank 2015, 2016). Thanks to high commodity prices and increased

\footnotetext{
${ }^{10}$ On the interplay of Bolivia's contributory and non-contributory pension schemes see Lloyd-Sherlock/Artaraz (2014).
} 
mineral and natural gas exports, economic growth averaged 4.9\% between 2004 and 2014 . Around half of Bolivia's exports and fiscal revenues depend on hydrocarbons, however. After continous surpluses between 2006 and 2013, the fiscal balance plunged into deficit when international oil prices started plummeting in mid-2014, while current accounts were to follow in 2015 (World Bank 2015; DB Research 2015). Prices for Bolivia's natural gas exports are fixed quarterly based on a basket of fuel prices, who thus have a delayed effect on natural gas export prices. Impressive international reserves, standing at $42 \%$ of GDP, will serve as a buffer (Ogawa 2015). The government faces the challenge of maintaining positive economic and social results in a much less favourable international context. The president's latest idea to increase Renta Dignidad by 50 Bs. in kind - national products to boost Bolivia's internal market (La Razón 2016) - may be a foretaste. ${ }^{11}$

\section{Caught between two stools? Bolivia's universal pensions, social policy regimes, and changing development paradigms in Latin America}

In a region widely characterised by commodified social policy, exclusionary labour markets, and critical welfare production through families and social support networks, Bolivia's Bonosol and Renta Dignidad amount to a "significant precedent by introducing rights beyond the market" (Crabtree/Whitehead 2001: 220). The above account has revealed some political economy puzzles associated with this precedent: a neoliberal government (Gonzalo Sánchez de Lozada, 1993-97 and 2002-03) introducing decommodified benefits, and a left-wing government (Evo Morales, since 2006) not enthusiastic about a universal pension but finally coming to terms with it. Possible implications of neo-extractivism for Bolivia's universal pension are an issue, too. To shed further light on these matters, we will now consult the relevant literature on welfare regimes and changing development paradigms in Latin America.

\section{Bolivia's universal pensions and social policy regimes}

Clearly, Esping-Andersen's well-known, much-discussed typology of welfare-state regimes is of no help here. The "liberal welfare state" comes with means-tested social assistance (EspingAndersen 1990: 26-27), not unconditional cash transfers. Decommodification and universalism are characteristic of the "social democratic regime-type" (Esping-Andersen 1990: 27-28), yet neither Sánchez de Lozada nor Morales have ever considered themselves social democrats. Moreover, the MAS government was initially struggling with the idea of a universal pension. Most importantly, however, Esping-Andersen's regime types were developed for welfare states in the the North (Midgley 1997; Gough 2013).

When it comes to the global South, there is no consensus on welfare regimes, or social policy regimes, either, and Latin America is no exception (Pribble 2011; Andrenacci 2012; Seekings 2012). Most authors prefer typologies to account for the region's heterogeneity, while not always including the Bolivian case. ${ }^{12}$ In her much-cited approach, Martínez Franzoni (2008:

\footnotetext{
${ }^{11}$ Though known as a cash transfer, it had always been possible in principle to pay Renta Dignidad in cash/and or kind (Ley No. 3791, Art. 10).

${ }^{12}$ For example, Pribble (2011) disregards Bolivia due to problems with the quality of data.
} 
87-88) labels Bolivia "informal-familialist". Countries in this cluster have a largely informal labour market, residual social policy, and much of the population below the poverty line. As these countries do not succeed in commodifying labour and provide only minimally decommodified social protection, extended families play a pivotal role. Interestingly, however, the author observes that since the 1990s, even right-wing governments have sought to expand expenditures on targeted social assistance there (Martínez Franzoni 2008: 91). Martínez Franzoni and Sánchez-Ancochea (2012) also note the adoption of policies more sensitive to social incorporation, including the creation of innovative social programmes operating in a noncommodified or decommodified fashion.

In his widely-quoted analysis, Barrientos $(2004,2012)$ identifies a single, but changing, welfare regime for Latin America, currently the "liberal-informal welfare regime". The author stresses its dual nature, with one set of institutions for workers in formal employment and another one for workers in low income and informal employment. The latter segment is addressed by the rapidly expanding social transfer schemes that Latin America has witnessed over the last two decades. Here, the author explicitly mentions Bolivia's universal pension (Barrientos 2012: 134).

In a paper on social policy in mineral-rich countries, Bolivia is assigned to the "informal security regime" (Hinojosa/Bebbington/Barrientos 2012: 113). This regime type implies heavy reliance upon community and family to meet security needs. ${ }^{13}$ Yet, the authors highlight Bolivia's move towards a stronger role of the state in social provision, with the universal social pension cited as a key example. Whenever the tax system enables a country to capture a large proportion of the mineral revenue, the authors argue, mineral wealth may create fiscal space for social welfare provision, including entitlements as a matter of citizenship and rights, yet introducing external dependence (Hinojosa/Bebbington/Barrientos 2012: 114).

When discussing pension rights beyond the market in Latin America, it should be noted that decommodification is a contentious issue when it comes to the global South. According to Gough (2013: 212), the "very notion of decommodification does not make sense when economic behaviour is not commodified". Rudra (2007), however, distinguishes "protective" and "productive" welfare states, with the former focussing on decommodification and the latter prioritising commodification, pulling people into wage labour. "Dual" welfare states combine both approaches. ${ }^{14}$ Without a doubt, in Latin America, a large proportion of the population is unable to commodify its labour (Martínez/Molyneux/Sánchez-Ancochea 2009: 4), and thus to collect a contributory pension in old age. This is one of the reasons why social transfers, directed to those at the margins of formal labour markets, have been expanded in recent years (Ossio 2009). Bolivian old-age security clearly exhibits a partial "switch from a workerprotection design to a citizen-protection design” (Bosch/Melguizo/Pagés 2013: 84).

This look at the literature on social policy regimes in the global South, and Latin America in particular, has contributed to some of the issues raised above. We will now look at the

\footnotetext{
${ }^{13}$ On the "informal security regime" and "insecurity regime", as opposed to welfare-state regimes see Wood/Gough (2006) and Gough (2013).

${ }^{14}$ Bolivia is in Rudra's "protective" welfare state category (2007: 389). Yet, Barrientos (2012: 129) argues that due to the low benefit level, the "new forms of social assistance in Latin America are strongly 'productivist". Lavinas/Simões (2015) claim that CCTs may lead to commodification and monetization in subsistence-based parts of Latin America.
} 
changing development paradigms involved in the Bolivian case in search for further insights. As pointed out by Seekings (2012: 29): “There are diverse pathways towards redistributive, pro-poor welfare reforms".

\section{Bolivia's universal pensions between neoliberalism and new extractivism}

Elderly poverty and universal pensions were not on the radar of Bolivia's neoliberals in the 1990s (Instituto Prisma 2000). Instead, the policy prescriptions of the Washington Consensus were followed, implying a move from state to market in both economic and social policy (Williamson 1994, 2000). Sánchez de Lozada had promised to distribute the shares of state-owned enterprises free of charge among all adult Bolivians, a form of mass privatisation practised in East Europe during the transition from state to market. After the cancellation of this plan in Bolivia, the capitalisation of state-owned enterprises was linked to pension privatisation. When the second leg of those twin reforms stalled, the Bonosol scheme was invented. A tangible benefit to elderly citizens, conditional on the introduction of mandatory private pension funds, its function was to push an essentially macroeconomic agenda. Intended to ease opposition to two difficult reforms, it has been dubbed "a neopopulist solution to a neoliberal problem" (Durana 2012: 60).

The Bonosol was thus not conceived as a universal pension in its own right but instrumental in a context of neoliberal structural reform. As part of a political package deal, the benefit was strongly contested. Moreover, the Bonosol's financial architecture soon backfired. Its intimate link to Bolivian-style privatisation, the key neoliberal reform of the 1990s, anchored it firmly in the neoliberal agenda, a considerable drawback when the development paradigm changed in 2003. After the Bonosol had been devised by neoliberal structural reformers under pressure, it was challenged first by the IFIs and then by the left, thus seemingly caught between two stools.

The main focus of Bolivia's left-wing government was economic, not social - an interesting parallel to its neoliberal predecessors, albeit with a very different agenda. Now, the Bonosol was not only perceived as a leftover of abhorred neoliberalism, through its peculiar financial architecture it also obstructed the left's economic project. In terms of social policy, the Bolivian left traditionally focused on workers ("activos"), not the elderly, denoted as passive ("pasivos"). Hence, it took some time until the Morales government finally came to terms with the idea of a universal pension.

With the introduction of Renta Dignidad in 2008, Morales symbolically discontinued Sánchez de Lozada's brainchild, while adapting the universal pension to the needs of neoextractivism. Renta Dignidad was also declared part of Bolivia's strategy to achieve the Millennium Development Goals (HAI 2007). The fact that Renta Dignidad is largely financed by the IDH, originally destined for "education, health, roads, productive development and all that contributes to the creation of jobs" (Ley No. 3058, Art. 57), underlines the change of mind by Bolivia's neo-extractivist government in terms of the road towards social justice (ABI 2008).

The key economic project of Bolivia's "new developmentalism" (Bresser-Pereira 2011), or "new extractivism" (Gudynas 2010), was the re-nationalisation of the oil and gas sector, on which the Bonosol had relied for funding and on which Renta Dignidad now depends through 
the IDH. "Latin America has switched from the Washington Consensus ... to the Commodities Consensus" (Svampa 2013: 117), with Bolivia among the leaders of re-primarisation (Matthes 2012). This development strategy and its concomitant social policy have been called into question by some authors, however, even if promoted by progressive governments, or precisely because of this. ${ }^{15}$

Svampa (2013: 126) discusses social policy and new extractivism in Latin America and concedes that "the nation state has recovered institutional tools and options by becoming an economically relevant player and, in certain cases, an agent of redistribution”. Acosta (2013: 73) agrees, but misses "a radical redistribution of income and wealth". Moreover, with reference to CCT programmes, he censures what he calls a "clientelist 'bonocracy" (cited in Plataforma Energética 2010 and Veltmeyer 2014: 99). ${ }^{16}$ Gudynas' concern is more complex:

"[T]he state seeks to capture surpluses from extractivism, and then uses part of them in these social programs, managing to use this social legitimacy to defend its extractive activities. ... [T] hese social activities need increasing financing, and thus these same governments become dependent on extractivism" (Gudynas 2010: 8).

If at all, cash transfer programmes are only accepted as temporary anti-poverty measures with the exception of the basic income (Gudynas 2012: 157). As an unconditional basic pension, Bolivia's Renta Dignidad is rather close to the basic income. Still, Bolivia's universal pension is not mentioned in any of these analyses. The only author explicitly referring to Renta Dignidad is Veltmeyer (2014: 99), yet mixing this unconditional benefit with conditional cash transfers. In his view, such programmes are a "irresponsible waste of fiscal resources based on mining and oil rents" (Veltmeyer 2014: 95). ${ }^{17}$ To sum up, there is still no consensus on universal pensions across development schools, or among the left. The new direction in Latin American social policy - expanding coverage and emphasising universalism and citizenship rights is not easily accommodated in this body of literature.

As a postscript, it should be pointed out that the cited analyses, calling for a "postextractivist economy" (Acosta 2013: 80) or even “post-developmentalism” (Svampa 2013: 128), were written in the times of Latin America's resource bonanza. Contrary to this, Bolivia's progressive neo-extractivism is now confronted with the end of the commodities boom. Its vulnerability to commodity prices, highlighted by Hinojosa/Bebbington/Barrientos (2012: 114), has now turned obvious.

But is Renta Dignidad really an "irresponsible waste of fiscal resources"? The following section will discuss the universal pension's merits and drawbacks from a social policy perspective.

\footnotetext{
${ }^{15}$ For this critique of the left by the left, with economic, ecological and political arguments, see Gudynas (2010, 2012), Acosta (2010), Svampa (2013), Burchardt/Dietz (2014) and Veltmeyer/Petras (2014).

${ }^{16}$ In Bolivia, CCT programmes include "Bono Juancito Pinto" for school age kids and "Bono Juana Azurduy" for pregnant women and newborns (see Chapter 2.5), but not the universal pension.

${ }^{17}$ See also Acosta, as cited in Plataforma Energética (2010).
} 


\section{A critical appraisal of Bolivia's universal pension schemes}

Twenty years ago, the introduction of the non-contributory scheme was described as "unusually ambitious attempt to provide egalitarian welfare benefits in a very poor country" (Whitehead 1997: 89). Bolivia is indeed South America's poorest country, with a gross national income (GNI) per capita of US $\$ 2,870$ in 2014. Back in 1997, its GNI per capita was as low as US\$960 (World Bank 1997, 2016). ${ }^{18}$

Nevertheless, Bolivia is the only Latin American country to afford a universal noncontributory pension - the obvious answer to the near-total absence of contributory pensions. Both the proportion of active contributors and the proportion of elderly recipients of contributory pension is extremely low (OECD/IDB/World Bank 2014: 14-15). In 2011, only 10.7\% of Bolivians between 60 and 64 years of age and 16\% of those aged 65 and above received a contributory pension. Coverage was somewhat higher in urban areas, while in rural areas the figures were only $4.2 \%$ and $8.9 \%$, respectively, and coverage of women was lower than of men (UDAPE 2013; UNFPA Bolivia 2016).

Before the launch of non-contributory pensions, elderly Bolivians were poorer than the population at large. Back in 1992, the poverty rate of Bolivians aged 60 and above was $72.1 \%$, compared with an average poverty rate of 70\% (INE et al. 2003: 24; Baldivia Urdininea 2000: 89). Strikingly, only $1 \%$ of the rural elderly lived above the poverty line (Bauer/Bowen 1997; UDAPE 2000). In 2001, during the short spell of Bolivida, $63 \%$ of Bolivians aged 60 and above were poor, compared with $58.6 \%$ of the population at large. $30 \%$ of the elderly were indigent, compared with an average of $21.7 \%$. Moreover, no less than $93 \%$ of the rural elderly were poor (INE et al. 2003: 22-25).

Two decades of universal pensions have changed the picture. "There is little evidence that the elderly are poorer than the non-elderly" (OECD/IDB/World Bank 2014: 25). Based on a US\$2.50-a-day poverty line, Cotlear and Tornarolli (2011: 88) found that 35\% of Bolivians were poor, but only $26.6 \%$ of those older than age 60 . In rural areas, overall poverty was $62.7 \%$ and old-age poverty $46 \%$, while in urban areas, overall poverty stood at only $19.4 \%$ and oldage poverty at $9 \%$. A survey carried out in 2011 found that the poverty rate of households receiving Renta Dignidad was 13.5 percentage points lower than in the control group (Escobar Loza/Martínez Wilde/Mendizábal Córdova 2013: 89). ${ }^{19}$ A recent report put relative poverty rates $(50 \%$ median per capita) at $18 \%$ for the elderly and $26 \%$ for the population at large (OECD/IDB/World Bank 2014: 25). All of these studies explicitly mention the favourable impact of Bolivia's large social pension programme on old-age poverty.

When the universal pension was first introduced in 1997, the benefit level was only 1,300 Bs. (then US\$248) p.a., yet amounting to $42 \%$ of the annual minimum wage and $27 \%$ of Bolivia's per capita income (Ballivián 1997). Table 1 shows that the benefit amounts of both Bonosol and Renta Dignidad have since been increased, now reaching the equivalent of US\$460 p.a. $(3,250$ Bs.) for those with no contributory pension, an $85 \%$ hike (150\% in domestic currency).

\footnotetext{
18 Then as now, however, the country was classified as "lower middle income" by the World Bank $(1997,2016)$. Thus, by global standards, Bolivia is not "very poor".

${ }^{19}$ The control group consisted of households where the eldest member was just below the eligibility age for the universal pension (Mendizábal/Escobar 2013: 1).
} 
However, Renta Dignidad did not keep pace with the increasing minimum wage and growing per capita income, falling to only $16 \%$ of the former's 2015 amount and the latter's 2014 value. This raises concerns over the universal pension's adequacy. Bosch/Melguizo/Pagés (2013: 38) point out that the benefit amount is below the absolute poverty line of US $\$ 2.50$ per day, based on PPP. ${ }^{20}$ At one point, even the IMF recommended " $[\mathrm{m}]$ aintaining the real value of cashtransfer programs to preserve their impact” (IMF 2012b: 4). While Evo Morales recently considered an increase by a mere 50 Bs. (US\$7), elderly Bolivians were rallying for an equalization of Renta Dignidad with the minimum wage (La Razón 2016).

In spite of its low benefit amount, Bolivia's universal pension has made a big difference to the elderly (Vargas/Garriga 2015: 5). The non-contributory pension was often the only cash income they could count on, especially in rural areas. In a survey on the annually-paid Bonosol, $50 \%$ of interviewees declared it was their only income (SPVS 2004). Recipients of Renta Dignidad can draw the benefit on a monthly, quarterly, semi-annual or annual basis, whatever suits them best - small amounts for those unable to make the money last for a whole year or lack safe storage facilities, or larger amounts for investment in economic activities such as farming.

A survey conducted in 2011 found that household income per capita increased by $16.4 \%$ and consumption per capita rose by $15.4 \%$ when an individual reached eligibility age (Escobar Loza/Martínez Wilde/Mendizábal Córdova 2013). Renta Dignidad was spent mainly on food (52\%), but also on health (9\%), utilities (8\%), savings (7\%), clothing and shoes (6\%), and transportation (4\%). An impact study on the Bonosol highlighted the dynamic effects of the universal pension:

"Cash transfers to poor and liquidity constrained households can unleash productive potential through investments in household economic activities such as farming, which in turn increase consumption through multipliers on the transfer" (Martinez 2004: 23-24).

Skinner (2006: 156-164) found that the Bonosol not only impacted on financial and physical capital. The universal pension also increased social and human capital, with the elderly having a chance to contribute to family and community networks, instead of being net recipients of support, and investing in health, nutrition and education. Martínez $(2004,2006)$ found that in rural areas with a high concentration of poor households, the benefit achieved large increases in food consumption, and children in beneficiary households showed increased school enrolment. Mendizabal/Escobar (2013) argue that in households receiving the universal pension, children are less likely to work and more likely to attend school. Overall, receipt of Renta Dignidad led to a reduction in both objective and subjective poverty in households with older persons.

In the early years, the non-contributory pension's coverage and outreach to the poorest was a concern. MECOVI survey results showed that in 2001, Bolivida's coverage was $70.8 \%$ overall, but only $37.4 \%$ in the first decile and a meagre $36.1 \%$ in the rural first decile (Aponte et al. 2006: 229). Thus, initially, those who needed the non-contributory pension most were

\footnotetext{
${ }^{20}$ A recent study on chronic poverty in Latin America uses the same poverty line of US $\$ 2.5$ a day to define the extreme poor (Vakis/Rigolini/Luchetti 2015: 8).
} 
least likely to have access to it. These groups often lived far away from the AFPs' branch offices, thus needing substantial amounts of money and time to collect the benefit. Under the Renta Dignidad scheme, the range of eligible financial entities was substantially increased, and in some instances, units of the Bolivian military helped to reduce beneficiaries' travel time and costs. Payable upon presentation of one's identity card, the non-contributory pension was, in theory, simple to collect. Yet, elderly slum dwellers and rural inhabitants of Bolivia were least likely to meet this prerequisite (HAI 2004). Some of them did not have any identity papers or presented irregular documentation. These challenges have since been addressed. By increasing access to regular documentation, notably among the rural poor, the universal pension also had a positive impact on citizenship (Skinner 2006; Hunter/Brill 2016). MECOVI survey results found that by $2003 / 04$, the Bonosol's coverage had improved to $78.5 \%$ overall, $58.2 \%$ in the first decile and 57.1\% in the rural first decile (Aponte et al. 2006: 231). Recent data show that Renta Dignidad's coverage is now well above $90 \%$ and thus virtually universal (Ticona Gonzales 2011: 55; Mendizabal/Escobar 2013: 6; OECD/IDB/World Bank 2014: 30). This has also contributed to narrowing the gap in pension coverage between men and women (Bosch/Melguizo/Pagés 2013: 40).

In public debate, Bolivia's universal pension scheme was initially criticised for a purported lack of targeting. However, means testing is not a good option in a context of widespread poverty and weak administrative capacity, implying costs, bureaucracy and leeway for clientelism and fraud (Johnson/Williamson 2006; Larrazábal Antezana/De La Barra Muñoz 1997). A universal pension is the simplest administrative structure, coming with low transaction costs. Moreover, as demogrants, Bonosol and Renta Dignidad do apply a form of targeting, namely categorical targeting - a concept based on certain observable features of the individual (e.g. age) or the household (e.g. the presence of vulnerable groups). As Bolivia's elderly were statistically poorer than average citizens, they were targeted with good reason. Since 2008, Bolivia's universal old-age benefit is pension-tested, resulting in lower pay-outs for recipients of contributory pensions, thus meeting popular criticism (Skinner 2006: 169).

Besides challenging the prevailing targeting paradigm in Latin America, the universal pension scheme also runs counter to traditional approaches to development, which censure consumption as growth-reducing and see investment as a panacea. This logic was entrenched among Bolivia's policymakers and development community. Hence, the Bonosol was criticised for financing "consumption (by old people) and not investment in either human capital or infrastructure" (Morales 2001: 55). Moreover, it was censured as "unproductive spending of resources generated by productive sectors" (Instituto Prisma 2000: 20). On a strikingly similar line of argument, social programmes financed by new extractivism have been criticised as "irresponsible waste of fiscal resources" (Veltmeyer 2014: 95). This astounding common ground between neoliberals and parts of the left on universal cash transfers is particularly surprising as there is no trade-off between consumption and investment when it comes to Bolivia's universal pension, as noted above (Martínez 2004, 2006). The available evidence suggests that fiscal resources spent on Renta Dignidad were put to good use.

Financial sustainability was an issue, however (Hinojosa 2011: 501). Liquidity problems faced by the Bonosol in 1997 and 2003 did not help to create the image of an affordable benefit. In 2007, an FCC shrunk by Morales' re-nationalisation project challenged the Bonosol's 
financial architecture in a more fundamental way. New sources of financing had to be found for Bolivia's universal pension. Through the IDH, the universal pension's tie to hydrocarbons is only perpetuated, however. With a substantial tax hike after re-nationalisation, Bolivia experienced a marked increase in revenue collection and spent an annual 1 to $1.4 \%$ of GDP on the universal pension scheme (IMF 2012a: 34; Bosch/Melguizo/Pagés 2013: 13). US\$400 million p.a. are needed to finance Renta Dignidad (Vargas/Garriga 2015: 12). The shift from dividends to tax-financing did not come without risks, as the post-bonanza years show.

Finally, political sustainability was another long-standing issue. Instrumentalised from the start, the Bonosol was used in the MNR's policy reforms and electoral campaigns of 1997 and 2002. The 1997 election was lost by the MNR, however, thus possibly supporting the finding that targeted redistributive programmes do not necessarily help incumbents to win elections (Sanches Corrêa/Cheibub 2016), as had been widely believed. ${ }^{21}$ At any rate, the early politisation of the Bonosol, dubbed a "political football" (Brill 2013: 6), left the universal pension tainted and made it more difficult to create a consensus across Bolivia's political elites, both on the need to alleviate old-age poverty and on the usefulness of non-contributory pensions to achieve this. The political turmoil surrounding the distribution of the IDH and the lack of consensus-building during the legislative process seemed to point to a continuation of this detrimental course. Yet, through the subsequent anchoring of the universal pension in the constitution, viewed as a "new social contract" (UNRISD 2013: 1; Lloyd-Sherlock/Artaraz 2014: 269), the universal pension has since been consolidated both legally and politically. The popular universal pension now enjoys broad support throughout Bolivian society.

\section{Conclusions}

South America's poorest country, Bolivia, features the region's only universal, noncontributory old-age pension scheme. The scheme's 20-year history started with the Bonosol, tied to neoliberal structural reforms and replaced by a tax-financed scheme, Renta Dignidad, in 2008. Although threatened and adapted several times, Bolivia's universal pension scheme has survived all vicissitudes so far. Two decades after its introduction, the universal pension is not only seen as an acquired right by its elderly recipients but also anchored in Bolivia's constitution.

Before, there was not much awareness of the urgent needs of Bolivia's elderly population, whose deserving of parts of government spending was highly contested. The universal pension's challenge to conventional approaches to development and targeting implied that Bolivia's current developmentalist government also took some time to discover the benefit's potential contribution to its social justice agenda. At the time of writing, with collapsing commodity prices and Evo Morales narrowly losing his reelection bid, future challenges may well be ahead.

Owing to the Millennium Development Goals, the Social Protection Floor Initiative and the Sustainable Development Goals, a human rights approach to cash transfers has gained in prominence, and non-contributory pensions are intriguing the international social policy and

\footnotetext{
${ }^{21}$ The focus of this debate is on CCTs, Latin America's mainstream social programmes, however.
} 
development community.22 With the move towards universalism and citizenship rights still not easily accommodated in the literature on social policy regimes and development paradigms in the global South, the Bolivian experience may provide useful lessons on pitfalls and potentials to policymakers elsewhere, not least on the mobilization of necessary resources (see also Hujo/McClanahan 2009; Hujo 2012; Barrientos 2013).

With its proven record in poverty reduction, Bolivia's universal pension is a "prudent investment" (Aponte et al. 2006), not a mere clientelist manoeuvre and certainly not a waste of fiscal resources. Overarching the country's conflicting political and economic projects, it sets a significant precedent in decommodification in an unlikely context.

\section{References}

ABI (2008). La renta Dignidad reducirá la pobreza y las asimetrías entre pobres y ricos. http://comitedeapoyoabolivia.blogspot.de/2008/01/la-renta-dignidad-reducir-la-pobreza-y.html [accessed February 5, 2016].

Acosta, Alberto (2013). Extractivism and neoextractivism: two sides of the same curse. In: Lang, Miriam and Dunia Mokrani (eds.). Beyond Development. Alternative visions from Latin America (6186). Quito \& Amsterdam: Fundación Rosa Luxemburg \& Transnational Institute.

Andrenacci, Luciano (2012). From Developmentalism to Inclusionism: On the Transformation of Latin American Welfare Regimes in the Early 21st Century. Journal für Entwicklungspolitik, XXVIII(1), 35-57.

Aponte, Guillermo et al. (2006). La inversión prudente. Impacto del Bonosol sobre la familia, la equidad social y el crecimiento económico. La Paz: Fundación Milenio.

APS (2015). Estadísticas de la Renta Dignidad. Autoridad de Fiscalización y Control de Pensiones y Seguros. http://www.aps.gob.bo/estadisticas/Paginas/Renta-Dignidad.aspx [accessed February 11, 2016].

Baldivia Urdininea, José (1998). La capitalización. Apuntes para una evaluación. In: Chávez Corrales, Juan Carlos (ed.). Las reformas estructurales en Bolivia (53-123). La Paz: Fundación Milenio.

Baldivia Urdininea, José (2000). Las políticas sobre la pobreza en Bolivia. In: Instituto Prisma (ed.). Las políticas sobre la pobreza en Bolivia. Dimensión, políticas y resultados (1985-1999) (31-167). La Paz: Plural Editores.

Ballivián, Amparo (1997). Pension Reform in Bolivia: Fiscal and Social Impacts. World Bank Draft Discussion Paper. Washington DC, mimeo.

Barrientos, Armando (2004). Latin America: towards a liberal-informal welfare regime. In: Gough, Ian et al. Insecurity and Welfare Regimes in Asia, Africa and Latin America: Social Policy in Development Contexts (121-168). Cambridge et al.: Cambridge University Press.

Barrientos, Armando (2012). Accounting for change in Latin America's welfare regime. In: Burchardt, Hans-Jürgen, Anne Tittor and Nico Weinmann (eds.). Sozialpolitik in globaler Perspektive - Asien, Afrika und Lateinamerika (119-139). Frankfurt \& New York: Campus.

\footnotetext{
${ }^{22}$ See, e.g., Leisering/Buhr/Traiser-Diop (2006), Künnemann/Leonhard (2008), Leisering (2008), Hanlon, Barrientos and Hulme (2010), Barrientos (2013), Deacon (2013) and Gliszczynski (2015).
} 
Barrientos, Armando (2013). Social Assistance in Developing Countries. Cambridge: Cambridge University Press.

Barrientos, Armando and Peter Lloyd-Sherlock (2002). Non-contributory pensions and social protection. Social Protection Sector, Issues in Social Protection, Discussion Paper 12. Geneva: International Labour Organization.

Bauer, Richard and Sally Bowen (1997). The Bolivian Formula: From State Capitalism to Capitalisation. Santiago de Chile: McGraw-Hill \& Interamericana de Chile.

Bosch, Mariano, Ángel Melguizo and Carmen Pagés (2013). Better Pensions, Better Jobs: Towards Universal Coverage in Latin America and the Caribbean. Washington DC: Inter-American Development Bank.

Bresser-Pereira, Luiz Carlos (2011). From old to new developmentalism in Latin America. In: Ocampo, José Antonio and Jaime Ros (eds.). The Oxford Handbook of Latin American Economics (108129). Oxford: Oxford University Press.

Brill, Robert Jeffrey (2013). Noncontributory Pensions, Cash Transfers, and Documentation in Brazil and Latin America. Professional Report. Lyndon B. Johnson School of Public Policy, University of Texas at Austin, mimeo.

Burchardt, Hans-Jürgen and Kristina Dietz (2014). (Neo-)extractivism - a new challenge for development theory from Latin America. Third World Quarterly, 35(3), 468-486.

CNJRB (1998). Memoria del III Congreso Nacional. La Paz: Confederación Nacional de Jubilados y Rentistas de Bolivia.

Cotlear, Daniel (2011). Population Aging: Is Latin America Ready? In: Cotlear, Daniel (ed.). Population Aging. Is Latin America Ready? (1-41).Washington DC: World Bank.

Cotlear, Daniel and Leopoldo Tornarolli (2011). Poverty, the Aging, and the Life Cycle in Latin America. In: Cotlear, Daniel (ed.). Population Aging. Is Latin America Ready? (79-134). Washington DC: World Bank.

Crabtree, John and Laurence Whitehead (2001). Conclusions. In: Crabtree, John and Laurence Whitehead (eds.). Towards Democratic Viability. The Bolivian Experience (216-234). Basingstoke \& New York: Palgrave.

DB Research (2015). Bolivia. Frontier country report. November 12, 2015. Frankfurt: Deutsche Bank Research.

Deacon, Bob (2013). Global Social Policy in the Making. The foundations of the social protection floor. Bristol: Policy Press.

Decreto Supremo No. 28701 of May 1, 2006 (Héroes del Chaco).

Dethier, Jean-Jacques, Pierre Pestieau and Rabia Ali (2010). Universal Minimum Old Age Pensions. Impact on Poverty and Fiscal Cost in 18 Latin American Countries, World Bank Policy Research Working Paper 5292. Washington DC: World Bank.

Durana, Alieza (2012). Morales' Bolivia: A New Paradigm in Egalitarian Governance? The Washington University International Review, 1, 56-75. 
ECLAC (2015). Inclusive social development. The next generation of policies for overcoming poverty and reducing inequality in Latin America and the Caribbean. Santiago de Chile: Economic Commission for Latin America and the Caribbean.

Embajada de Bolivia en la República Argentina (2007). Respuestas a preguntas sobre la Renta Dignidad. Comunicado 059/2007. http://www.embajadadebolivia.com.ar/comunicado_059_2007.htm [accessed January 12, 2008].

Escobar Loza, Federico, Sebastián Martínez Wilde and Joel Mendizábal Córdova (2013). El impacto de la Renta Dignidad: Política de Redistribución del Ingreso, Consumo y Reducción de la Pobreza en Hogares con Personas Adultas Mayores. La Paz: UDAPE.

Esping-Andersen, Gøsta (1990). The Three Worlds of Welfare Capitalism. Princeton: Princeton University Press.

Gamarra, Eduardo A. (1997). Neoliberalism Reconsidered: The Politics of Privatization and Capitalization in Bolivia. In: Peirce, Margaret Hollis (ed.). Capitalization: A Bolivian Model of Social and Economic Reform (97-126). Miami: North South Center.

Gill, Indermit S., Truman Packard and Juan Yermo (2005). Keeping the Promise of Social Security in Latin America. Palo Alto \& Washington DC: Stanford University Press \& World Bank.

Ginneken, Wouter van (2007). Extending social security coverage: Concepts, global trends and policy issues. International Social Security Review, 60(2-3), 33-58.

Gliszczynski, Moritz von (2015). Cash Transfers and Basic Social Protection: Towards a Development Revolution? Basingstoke \& New York: Palgrave.

Gough, Ian (2013). Social policy regimes in the developing world. In: Kennett, Patricia (ed.). A Handbook of Comparative Social Policy (205-224). Cheltenham: Edward Elgar.

Graham, Carol (1998). Private Markets for Public Goods: Raising the Stakes in Economic Reform. Washington DC: Brookings Institution Press.

Gray-Molina, George, Ernesto Pérez de Rada and Ernesto Yañez (1999). La economía política de reformas institucionales en Bolivia. Documento de Trabajo R-350. Washington DC: Inter-American Development Bank.

Gudynas, Eduardo (2010). The New Extractivism of the 21st Century: Ten Urgent Theses about Extractivism in Relation to Current South American Progressivism. Americas Program Report. Washington DC: Center for International Policy. http://www10.iadb.org/ intal/intalcdi/PE/2010/04716.pdf [accessed February 11, 2016].

Gudynas, Eduardo (2012). Post-Extraktivismus und Transitionen auf dem Weg zu Alternativen zu Entwicklung. In: FDCL and RLS (eds.). Der Neue Extraktivismus - Eine Debatte über die Grenzen des Rohstoffmodells in Lateinamerika (144-161). Berlin: FDCL-Verlag.

HAI (2004). Age and security. How social pensions can deliver effective aid to poor older people and their families. London: HelpAge International.

HAI (2007). A better pension deal for older people in Bolivia. http://www.helpage.org/ News/Latestnews/Dle0 [accessed April 11, 2010].

Hanlon, Joseph, Armando Barrientos and David Hulme (2010). Just give money to the poor. The Development Revolution from the Global South. Sterling: Kumarian Press. 
Hillenkamp, Isabelle (2013). Solidarity and Protection in Bolivian Popular Economy. In: Hillenkamp, Isabelle, Frédéric Lapeyre and Andreia Lemaître (eds.). Securing Livelihoods. Informal Economy Practices and Institutions (47-63). Oxford: Oxford University Press.

Hinojosa, Leonith (2011). Riqueza mineral y pobreza en los Andes. European Journal of Development Research, 23(3), 488-504.

Hinojosa, Leonith, Anthony Bebbington and Armando Barrientos (2012). Social Policy and State Revenues in Mineral-Rich Countries. In: Hujo, Katja (ed.). Mineral Rents and the Financing of Social Policy. Opportunities and Challenges (91-121). Basingstoke \& New York: Palgrave.

Hodges, Tina (2007). Bolivia's Gas Nationalization: Opportunity and Challenges (2). http://ainbolivia.org/2007/12/bolivia\%E2\%80\%99s-gas-nationalization-opportunity-and-cha/ [accessed February 5, 2016].

Holzmann, Robert and Richard Hinz (2005). Old age income support in the 21st century. An international perspective on pension systems and reform. Washington DC: World Bank.

Hujo, Katja and Shea McClanahan (eds.) (2009). Financing Social Policy. Mobilizing Resources for Social Development. Basingstoke \& New York: Palgrave.

Hujo, Katja (ed.) (2012). Mineral Rents and the Financing of Social Policy. Opportunities and Challenges. Basingstoke \& New York: Palgrave.

Hunter, Wendy and Robert Brill (2016). "Documents, please". Advances in Social Protection and Birth Certification in the Developing World. World Politics, 68(2), 1-38.

ICG (2007). Bolivia's Reforms: The Danger of New Conflicts. Latin America Briefing No. 13. Bogotá \& Brussels: International Crisis Group.

ILO (2011). Social Protection Floor for a Fair and Inclusive Globalization. Geneva: International Labour Organization.

Instituto Prisma (ed.) (2000). Las políticas sobre la pobreza en Bolivia. Dimensión, políticas y resultados (1985-1999). La Paz: Plural Editores.

Johnson, Jessica K. M. and Johan B. Williamson (2006). Do universal noncontributory old-age pensions make sense for rural areas in low-income countries? International Social Security Review, 59(4), 47-65.

Künnemann, Rolf and Ralf Leonhard (2008). A human rights view on the potential of social cash transfers for achieving the millennium development goals. Stuttgart, Bonn \& Frankfurt: Brot für die Welt, Evangelischer Entwicklungsdienst \& Medico International.

IMF (2007). Bolivia: Staff Report for the 2007 Article IV Consultation. Washington DC: International Monetary Fund.

IMF (2012a). Bolivia: Staff Report for the 2012 Article IV Consultation. Washington DC: International Monetary Fund.

IMF (2012b). IMF Executive Board Concludes 2012 Article IV Consultation with Bolivia. Public Information Notice (PIN) No. 12/57. June 7, 2012. Washington DC: International Monetary Fund.

IMF (2015). Bolivia: Staff Report for the 2015 Article IV Consultation. Washington DC: International Monetary Fund. 
INE, UNFPA, HAI and DFID (2003). Bolivia: Situación Sociodemográfica de la Población Adulto Mayor. La Paz: Instituto Nacional de Estadística.

La Razón (2007a). Evo anula el Bonosol y crea una renta de Bs 200 al mes, October 14, 2007. http://www.la-razon.com/versiones/20071014_006059/nota_249_493222.htm [accessed January $13,2008]$.

La Razón (2007b). El Gobierno pide la solidaridad para el Bonosol, October 10, 2007. http://www.larazon.com/Versiones/20071010_006055/nota_248_491385.htm [accessed October 10, 2007].

La Razón (2007c). El futuro del Bonosol deja de ser sostenible, April 28, 2007. http://www.larazon.com/Versiones/20070428_005890/nota_248_420353.htm [accessed May 9, 2008].

La Razón (2014). Gobierno inicia pago del aguinaldo de la Renta Dignidad en favor de 902.314 adultos mayores, November 15, 2014. http://www.la-razon.com/index.php?_url=/economia/Gobiernoaguinaldo-Renta-Dignidad-mayores_0_2162783764.html [accessed February 12, 2016].

La Razón (2016). Analizan subir Renta Dignidad en productos, February 1, 2016 http://www.larazon.com/economia/renta_dignidad-Analizan-subir-Renta-Dignidad-

productos_0_2428557157.html [accessed February 13, 2016].

Larrazábal Antezana, Erick and Víctor Hugo De La Barra Muñoz (1997). Capitalización y Pensiones: Análisis y Reflexiones sobre los Modelos de Reforma. La Paz: Sociedad de Análisis de Políticas Públicas.

Lavinas, Lena and André Simões (2015). Social Policy and Structural Heterogeneity in Latin America: The Turning Point of the 21st Century. In: Fritz, Barbara and Lena Lavinas (eds.). A Moment of Equality for Latin America? Challenges for Redistribution (77-102). Farnham \& Burlington: Ashgate.

Leisering, Lutz (2008). The rise of global social policy. Social assistance in developed and developing countries. SocialWorld Working Paper No. 15. Bielefeld: University of Bielefeld, Institute for World Society Studies.

Leisering, Lutz, Petra Buhr and Ute Traiser-Diop (2006). Soziale Grundsicherung in der Weltgesellschaft. Monetäre Mindestsicherungssysteme in den Ländern des Südens und des Nordens. Weltweiter Survey und theoretische Verortung. Bielefeld: transcript Verlag.

Ley No. 65 of December 10, 2010 (Ley de Pensiones).

Ley No. 1544 of March 21, 1994 (Ley de Capitalización).

Ley No. 2427 of November 28, 2002 (Ley del Bonosol).

Ley No. 3058 of May 20, 2005 (Ley de Hidrocarburos).

Ley No. 3791 of November 28, 2007 (Ley de la Renta Dignidad).

Lloyd-Sherlock, Peter and Kepa Artaraz (2014). Pension Reform in Bolivia: Two Models of Income Security in Old Age. In: Hujo, Katja (ed.). Reforming Pensions in Developing and Transition Countries (251-277). Basingstoke \& New York: Palgrave.

Martínez, Sebastian (2004). Pensions, Poverty and Household Investments in Bolivia. http:// eml.berkeley.edu/ webfac/bardhan/e271_f04/martinez.pdf [accessed February 5, 2016]. 
Martínez, Sebastián W. (2006). Invertir el Bonosol para aliviar la pobreza: retornos económicos en los hogares beneficiarios. In: Aponte, Guillermo et al. La inversión prudente. Impacto del Bonosol sobre la familia, la equidad social y el crecimiento económico (109-144). La Paz: Fundación Milenio.

Martínez Franzoni, Juliana (2008). Welfare Regimes in Latin America: Capturing Constellations of Markets, Families, and Policies. Latin American Politics and Society, 50(2), 67-100.

Martínez, Juliana, Maxine Molyneux and Diego Sánchez-Ancochea (2009). Latin American capitalism: economic and social policy in transition. Economy and Society, 38(1), 1-16.

Martínez Franzoni, Juliana and Diego Sánchez-Ancochea (2012). The Double Challenge of Market and Social Incorporation. Progress and Bottlenecks in Latin America. desiguALdades.net Working Paper 27/2012. Freie Universität Berlin.

Matthes, Sebastian (2012). Eine quantitative Analyse des Extraktivismus in Lateinamerika. Working Paper 02/2012. One World Perspectives, Universität Kassel.

Mendizábal, Joel and Federico Escobar (2013). Redistribution of wealth and old age social protection in Bolivia: The impact of the Renta Dignidad on the wellbeing of households with older persons. Pension Watch Briefing no. 12. London: HelpAge International.

Mercado Lora, Marcelo (1998). La reforma del sistema de pensiones de la seguridad social. In: Chávez Corrales, Juan Carlos (ed.). Las reformas estructurales en Bolivia (125-180). La Paz: Fundación Milenio.

Mesa-Lago, Carmelo (2008). Reassembling Social Security: A Survey of Pensions and Healthcare Reforms in Latin America. Oxford: Oxford University Press.

Mesa-Lago, Carmelo (2014). Reversing pension privatization: The experience of Argentina, Bolivia, Chile and Hungary. ESS Working Paper No. 44. Geneva: International Labour Organization.

Midgley, James (1997). Social Welfare in Global Context. Thousand Oaks: Sage Publications.

Ministerio de Capitalización (1997). Capitalización: El Modelo Boliviano de Reforma Económica y Social. La Paz, CD-ROM.

MNR and MRTK (1993). Bolivia: El Plan de Todos - Sintesis. La Paz, mimeo.

Morales, Juan Antonio (1995). Bolivia and the Slowdown of the Reform Process. PSD Occasional Paper No. 7. Washington DC: World Bank.

Morales, Juan Antonio (2001). Economic Vulnerability in Bolivia. In: Crabtree, John and Laurence Whitehead (eds.). Towards Democratic Viability. The Bolivian Experience (41-60). Basingstoke \& New York: Palgrave.

Müller, Katharina (2001). Die Privatisierung der bolivianischen Alterssicherung: eine Zwischenbilanz. In: Sevilla, Rafael and Ariel Benavides (eds.). Bolivien - das verkannte Land? (230-245). Bad Honnef: Horlemann.

Müller, Katharina (2003). Privatising Old-Age Security: Latin America and Eastern Europe Compared. Cheltenham: Edward Elgar.

Müller, Katharina (2009). Contested Universalism: From Bonosol to Renta Dignidad in Bolivia. International Journal of Social Welfare, 18(2), 163-172.

Müller, Katharina (2012). Alterssicherung zwischen Privilegien und sozialen Rechten: Befunde aus Lateinamerika. In: Burchardt, Hans-Jürgen, Anne Tittor and Nico Weinmann (eds.). Sozialpolitik 
in globaler Perspektive - Asien, Afrika und Lateinamerika (221-245). Frankfurt \& New York: Campus.

Nueva Constitución Política del Estado (2009).

OECD, IDB and World Bank (2014). Pensions at a Glance: Latin America and the Caribbean. Paris: OECD Publishing.

Ogawa, Sumiko (2015). Bolivia Faces Challenge of Adapting to Lower Commodity Prices. IMF Survey Magazine: Countries \& Regions, December 18, 2015. http://www.imf.org/external/pubs/ft/survey/ so/2015/CAR120815A.htm [accessed February 12, 2016].

Orenstein, Mitchell A. (2008). Privatizing pensions: The transnational campaign for social security reform. Princeton: Princeton University Press.

Orenstein, Mitchell A. (2011). Pension privatization in crisis: Death or rebirth of a global policy trend? International Social Security Review, 64(3), 65-80.

Ossio, Lorena (2009). La renta Dignidad y la pensión mínima en Bolivia. Instrumentos de protección para el sector informal laboral. http://aijdtssgc.org/2009/11/20/la-renta-dignidad-y-la-pensionminima-en-bolivia-instrumentos-de-proteccion-para-el-sector-informal-laboral/ [accessed $\mathrm{Fe}$ bruary 5, 2016].

Peirce, Margaret Hollis (ed.) (1997). Capitalization: A Bolivian Model of Social and Economic Reform. Miami: North South Center.

Pérez B., Martín (2000). Circuito político de una política pública: reforma al sistema de pensiones en Bolivia. La Paz, mimeo.

Plataforma Energética (2010). Latinoamérica despilfarra la renta petrolera y minera en "bonocracia". http://todos.plataformaenergetica.org/content/1909?page=1 [accessed February 15, 2016].

Pribble, Jennifer E. (2011). Worlds Apart: Social Policy Regimes in Latin America. Studies in Comparative International Development, 46(2), 191-216.

Rofman, Rafael (2006). Sistema de pensiones: las reformas de la reforma. In: Fretes-Ciblis, Vicente, Marcelo Guigale and Connie Luff (eds.). Bolivia. Por el bienestar de todos (391-411). Washington DC: World Bank.

Rofman, Rafael, Ignacio Apella and Evelyn Vezza (eds.) (2013). Más allá de las Pensiones Contributivas. Catorce experiencias en América Latina. Buenos Aires: Banco Mundial.

Rudra, Nita (2007). Welfare States in Developing Countries: Unique or Universal? Journal of Politics, 69(2), 378-396.

Sanches Corrêa, Diego and José Antonio Cheibub (2016). The Anti-Incumbent Effects of Conditional Cash Transfer Programs. Latin American Politics and Society, 58(1), 49-71.

Sánchez de Lozada, Gonzalo (1993). El Plan de Todos: Mensaje de Goni a los bolivianos, April 4, 1993. La Paz, mimeo.

Sánchez de Lozada, Gonzalo and Víctor Hugo Cárdenas (1993). Bolivia: El Plan de Todos. La Paz, mimeo.

Seekings, Jeremy (2012). Pathways to Redistribution: The Emerging Politics of Social Assistance Across the Global 'South'. Journal für Entwicklungspolitik, XXVIII(1), 14-34. 
Shahid, Ahmed (2014). Ageing with Dignity: Old-Age Pension Schemes from the Perspective of the Right to Social Security Under ICESCR. Human Rights Review, 15(4), 455-471.

Skinner, Emmeline (2006). Proteger y mejorar los medios de subsistencia de los adultos mayores: el rol del Bonosol en La Paz. In: Aponte, Guillermo et al. La inversión prudente. Impacto del Bonosol sobre la familia, la equidad social y el crecimiento económico (143-176). La Paz: Fundación Milenio.

SPVS (2000). Boletines de Pensiones, Superintendencia de Pensiones, Valores y Seguros, Julio-Diciembre 1999. La Paz, CD-ROM.

SPVS (2004). Resultados Encuesta Evaluación Bonosol. La Paz: Superintendencia de Pensiones, Valores y Seguros.

SPVS (2006). Boletín Estadístico Mensual, Noviembre de 2006, 32(3). La Paz: Superintendencia de Pensiones, Valores y Seguros.

Svampa, Maristella (2013). Resource Extractivism and Alternatives: Latin American Perspectives on Development. In: Lang, Miriam and Dunia Mokrani (eds.). Beyond Development. Alternative visions from Latin America (117-144). Quito \& Amsterdam: Fundación Rosa Luxemburg \& Transnational Institute.

Ticona Gonzales, Marcelo (2011). The Dignity Pension (Renta Dignidad): A Universal Old-age Pension Scheme. In: UNDP (ed.). Successful Social Protection Floor Experiences. Sharing Innovative Experiences (Vol. 18, 45-60). New York: United Nations Development Programme.

UDAPE (2000). Bolivia: Prospectiva Económica y Social 2000-2010. Cuaderno de Futuro No. 10. La Paz: Programa de las Naciones Unidas para el Desarrollo.

UDAPE (2013). Documento Descriptivo de Resultados de la Encuesta a Hogares con Personas Adultas Mayores y cercanas a la edad de 60 años - EPAM 2011. La Paz: Unidad de Análisis de Políticas Sociales y Económicas.

UN General Assembly (1948). Universal Declaration of Human Rights. General Assembly resolution 217 A (III). 183rd plenary meeting. Paris, December 10, 1948.

UNFPA Bolivia (2016). Personas Adultas Mayores. ¿Cuál es la situación de los/as adultos/as mayores en Bolivia? http://bolivia.unfpa.org/personas_adultas_mayores [accessed February 14, 2016].

UNRISD (2013). Contestation and Social Change: The Politics of Domestic Resource Mobilization in Bolivia. Project Brief 07, December 2013. Geneva: United Nations Research Institute for Social Development.

Vakis, Renos, Jamele Rigolini and Leonardo Lucchetti (2015). Left Behind. Chronic Poverty in Latin America and the Caribbean. Washington DC: World Bank.

Vargas, Mauricio and Santiago Garriga (2015). Explaining Inequality and Poverty Reduction in Bolivia. IMF Working Paper WP/15/265. Washington DC: International Monetary Fund.

Veltmeyer, Henry (2014). Bolivia: Between Voluntarist Developmentalism and Pragmatic Extractivism. In: Veltmeyer, Henry and James Petras (eds.). The New Extractivism. A Post-Neoliberal Development Model or Imperialism of the Twenty-First Century? (80-113). London \& New York: Zed Books.

Veltmeyer, Henry and James Petras (eds.) (2014). The New Extractivism. A Post-Neoliberal Development Model or Imperialism of the Twenty-First Century? London \& New York: Zed Books. 
Viceministerio de la Descentralización (2008). ¿Qué es la Renta Dignidad? http://www. descentralizacion.gov.bo/portal2/index.php?option=com_content\&task=view\&id=393\&Itemid=35 [accessed December 27, 2008].

Weyland, Kurt (2005). The Diffusion of Innovations. How Cognitive Heuristics Shaped Bolivia's Pension Reform. Comparative Politics, 38(1), 21-42.

Whitehead, Laurence (1997). Beyond Neo-liberalism: Bolivia's Capitalization as a Route to Universal Entitlements and Substantive Citizenship Rights? In: Peirce, Margaret Hollis (ed.). Capitalization: A Bolivian Model of Social and Economic Reform (71-95). Miami: North South Center.

Williamson, John (1994). In Search of a Manual for Technopols. In: Williamson, John (ed.). The Political Economy of Policy Reform (9-28). Washington DC: Institute for International Economics.

Williamson, John (2000). What Should the World Bank Think about the Washington Consensus? The World Bank Research Observer, 15(2), 251-264.

Willmore, Larry (2006). Non-contributory pensions: Bolivia and Antigua in an international context. Serie Financiamiento del Desarrollo No. 167. Santiago de Chile: CEPAL \& GTZ.

Withers-Green, Philip (2003). Bolivia: New law endangers private pension system. Pensions International, 47, 11-12.

Wood, Geof and Ian Gough (2006). A comparative welfare regime approach to global social policy. World Development, 34(10), 1696-1712.

World Bank (1995). Technical Annex - Financial Markets and Pension Reform Technical Assistance Project. Report No. T-6412-BO. Washington DC: World Bank.

World Bank (1997). World Development Report 1997. The State in a Changing World. Oxford: Oxford University Press.

World Bank (2000). Bolivia: Country Assistance Evaluation. Report No. 21412. Washington DC: World Bank.

World Bank (2015). Overview. http://www.worldbank.org/en/country/bolivia/overview [accessed February 12,2016$]$.

World Bank (2016). Data by Country: Bolivia. World Development Indicators. http://data.world bank.org/country/bolivia [accessed February 12, 2016].

Yanez-Pagans, Monica (2008). Culture and Human Capital Investments: Evidence of an Unconditional Cash Transfer Program in Bolivia. IZA Discussion Paper No. 3678. Bonn: Forschungsinstitut zur Zukunft der Arbeit. 